\title{
Work in Progress: Integrating Entrepreneurial Mind-set within Undergrad- uate Engineering Course Projects
}

\section{Dr. Anu Osta, Rowan University}

Dr Anu Osta is a Lecturer in Mechanical Engineering Department at Rowan University. His teaching interests are Engineering Mechanics, Materials Science and Manufacturing.

\section{Dr. Kevin D. Dahm, Rowan University}

Kevin Dahm is a Professor of Chemical Engineering at Rowan University. He earned his BS from Worcester Polytechnic Institute (92) and his PhD from Massachusetts Institute of Technology (98). He has published two books, "Fundamentals of Chemical Engineering Thermodynamics" and "Interpreting Diffuse Reflectance and Transmittance." He has also published papers on effective use of simulation in engineering, teaching design and engineering economics, and assessment of student learning. 


\title{
Work in Progress: Integrating Entrepreneurial Mindset within Undergraduate Engineering Course Projects
}

\begin{abstract}
Entrepreneurial mindset is important for maintaining a competitive edge in this dynamic and changing engineering world. The Kern Family Foundation through its Kern Entrepreneurial Engineering Network (KEEN) has made it its mission to equip engineers with an entrepreneurial mindset with the hope that this will contribute to business and technological success of the future U.S. workforce. This paper describes a work-in-progress intervention where the KEEN 3Cs of entrepreneurially minded learning (curiosity, connections, and creating value) were introduced into a 'Principles of MechE for ECE majors' course. In this course electrical engineering students learn about the basic principles of mechanical engineering. In an effort to understand how students view the $3 \mathrm{Cs}$, the students are asked to select a specific project which could be a new or a previous project from a different course. Through their project the students will highlight the following

- Curiosity

- $\quad$ Engineering Curiosity: The technological need for the product or solution. Technical description of integration of the related technologies for developing the product or the solution. The technological evolution or future of the solution.

- Business Curiosity: The market gap for a new product or solution. Causal factors and economic driving forces that point towards such a need.

- $\quad$ Connections

- $\quad$ Engineering Connections: Connections between the knowledge they have acquired in their various engineering courses and how they managed to draw upon those ideas and information with the current project.

- $\quad$ Business Connections: The professional connections that they established and how it all played in, in this particular project. Also if they were able to make a connection to the marketability of their ideas and how structured this idea was.

- $\quad$ Creating Value

- $\quad$ Engineering Value: What was the technological value invested and earned by this product or solution.

- $\quad$ Business Value: What was the economic value invested and earned by this product or solution.

The paper will document the experiences of implementing the above mentioned work in progress. Assessment criteria developed to measure the success of this effort will also be discussed such as the grading rubric. While this activity was integrated into a Mechanical Engineering course for ECE students, it could in principle be adapted to a wide variety of engineering courses at other universities.
\end{abstract}

\section{Introduction}

In today's competitive and fast changing socio-economic environment, the demand that the global job marketplace places on innovation and business calls for promoting creativity and critical thinking skills in all components of a college curriculum. The changing nature of job requirements worldwide requires in addition to the usual job skills, certain qualities like cultural adaptability, initiative, leadership, critical thinking, teamwork, and ability to handle vast amounts of information quickly. In the past decade there has been a transition into smart machines and 
systems, supercomputing, super structuring of organizations, a globally connected world, along with global competition for talent. Based on these experiences, the US National Academy of Engineering in 2008 identified 14 Grand Challenges for Engineering in the 21st Century [1, 2]. These were 14 game-changing goals for improving life on the planet, spanning four cross-cutting themes, namely sustainability, health, security, and joy of living. Following this several US universities adopted the Grand Challenges Scholars Programs (GCSP), a comprehensive research immersive program for the ambitious undergraduate students who wish to participate in solving the grand challenges to humanity. The GCSP identified five competencies to be achieved by a student in order to prepare them to address the Grand Challenges for engineering one of them being entrepreneurship. These competencies are Talent Competency, Multidisciplinary Competency, Viable Business/Entrepreneurship Competency, Multicultural Competency, and Social Consciousness Competency. In the United States entrepreneurial training was starting to get introduced across colleges and universities in the 1970's. Since then entrepreneurship education and training programs have expanded and been adopted in several more college and university curricula in recent years. It is estimated that $80 \%$ of all U.S. colleges and universities at present implement such programs [3]. Entrepreneurship for most of the students is a new experience. The benefits it offers includes the opportunity to acquire new skills and experience, access to knowledge and tools related to establishing and operating companies, decision making and negotiations, project management and team working and bearing consequences of undesired outcomes. Self-motivation, exploring new areas of interest and learning to identify business opportunities are some of the added benefits too. A key question however remains is how do we teach entrepreneurship?

The Kern Entrepreneurship Education Network (KEEN) initiative was launched in 2005 with this very mission to introduce the subject of entrepreneurial skills among engineering, science and technical undergraduates. Some of the values it stressed upon was characteristic of the entrepreneur, such as vision, passion, creativity, innovation, optimism, opportunity recognition and persistence. Its goal was to satisfy the industry's requirement for engineers with better communication and team working skills, engineers who had a broad understanding of how to solve real-world problems and create value in marketplace through innovation. KEEN's objectives can be broadly described as follows

1. To stress on promoting critical skills, capabilities and experiences

2. Making entrepreneurship and innovation education a priority

3. Encouraging cross-curriculum and interdisciplinary collaboration between students and faculty

4. Following curriculum, student, faculty and community centered activities, for example business plan competitions in schools, seminars focused on technology, workshops and conferences.

5. Using situation-based learning environment such as case studies.

The above efforts can together be summed up as building of an 'entrepreneurial mindset'. Entrepreneurial mindset, could be described as the inclination towards entrepreneurial activities, 
learning to deal with uncertainties and changes, and the drive towards pursuing innovation. An example of entrepreneurial mindset in a company would be the following indicators:

1) Seeking opportunities to solve problems for customers in a company,

2) Focusing on creating value for customers

3) Engaging the marketplace by being in contact with customers, and suppliers.

A study [4] into how the KEEN framework helps build interest in developing entrepreneurial mindset in engineering classroom, and its impact on student learning outcomes, revealed that KEEN-focused online discussions helped build technical interest in the topic, encouraged students to formulate questions, explore alternatives, and understand diverse perspectives. Some interesting questions however do remain when dealing with entrepreneurship education. Questions like, what should entrepreneurship education within the engineering context entail? To what extent should it be integrated into the engineering curriculum? How do the students respond to entrepreneurship education and its forms of pedagogy? A study [5] looking into the experiences of engineering students taking an entrepreneurship course was carried out where four different categories of experiencing entrepreneurship as part of an engineering degree program were identified. They were self-directed learning, a preparation for work life, a path to possible self-employment, and a context for developing leadership and responsibility for group achievement. Past studies by [3] provided new perspective on the process of creating entrepreneurial attitudes and norms, putting special emphasis on the various issues associated with entrepreneurship teaching. Pistrui [6] discussed the history of KEEN, and its implementation using case studies. Rae [7] explained the background rationale for the KEEN network in the US industrial context. According to them individuals with an entrepreneurial mindset

1. have an insatiable, dispositional curiosity to understand the changing world and its technical, societal, and economical aspects of problems, solutions, and opportunities;

2. make connections from many sources of information to enable insights and the development of creative solutions;

3. focus on creating value, broadly defined as value for others - this may be economic value but, importantly, it also includes societal and personal value.

They also described the 3C's of entrepreneurial mindset as

Curiosity

1. demonstrate constant curiosity about our changing world

2. explore a contrarian view of accepted solutions

Connections

3. integrate information from many sources to gain insight

4. assess and manage risk, e.g. interconnected ramifications

Creating value

5. identify unexpected opportunities to create value 
6. persist through and learn from failure, essential when iterating using stakeholder feedback

Liu [8] presents a multi-course problem-based learning (PBL) experience to foster the entrepreneurial mindset in the junior and senior mechanical engineering curriculum. Zappe [9] provides guidance for assessing curiosity in the engineering entrepreneurship education context. They focus on State Curiosity Vs Trait Curiosity and discuss various sources of evidence that can be used in the assessment process. Their central conclusion is that there is currently no clear best practice in existence for assessing curiosity as an element of the entrepreneurial mindset.

\section{Project Description}

The purpose of the present study was to kindle the entrepreneurial mindset among the electrical engineering students enrolled in 'Principles of MechE for ECE majors' course by having them analyze a typical course project along the guidelines of the KEEN framework. The idea was to encourage them to think about how well their project satisfied the 3C's. For the project the students were asked to form teams between 1 to 4 members. A set of instructions (described below) was provided and a case study of any previous course project was asked to be conducted. Each group had to choose an interesting project that they had been a part of either at the present institution or at a different one and examine it along the stipulated guidelines. The students had to briefly describe their project first in order to provide the reader with a background of the nature of the project work. Following this the team had to discuss the project in the following context

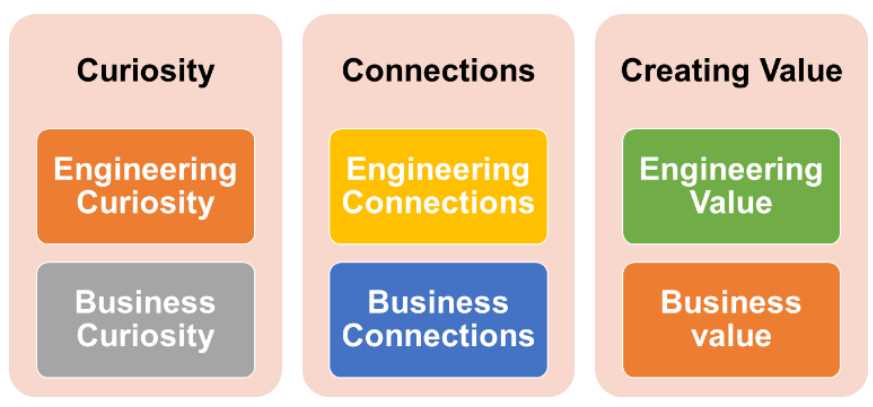

Figure 1. The basic framework of the project.

Engineering Curiosity: Discuss the technological need that the project fulfilled.

Were they developing a product or a technology? How did it answer the present technological needs of the society? How did they envision it to evolve over time?

Business Curiosity: Discuss on what gap in the market prompted for developing the product or the solution? What were the economic reasons that led to undertaking such a project?

Engineering Connections: Discuss what connections were the students able to make between the knowledge/experiences they acquired in their courses to the knowledge/ideas they had to apply in this project. 
Business Connections: Discuss what professional connections they were able to establish while working on this project. Were they able to make a connection between the project and its marketability?

Engineering Value: Discuss about the technological value invested in and the technological return on the project? Did their project contribute to some sort of technological advancement? If so how?

Business Value: Discuss about the economic value invested and earned by the project. Did their project create an economic value? What was this estimated value?

Table 1. Brief listing of the project titles and their descriptions

\begin{tabular}{|c|c|}
\hline TITLE & DESCRIPTION \\
\hline Accumulator Design for Formula SAE & Designing a battery pack for formula SAE car. \\
\hline Wireless Trailer Lights & LED's on trailer controlled by Arduino. \\
\hline Penetration Testing with Kali Linux & Finding vulnerabilities on Linux machines for cybersecurity. \\
\hline Virtual Reality Helicopter & Developing simulated helicopter flight on Unity 3D platform. \\
\hline BACard & Developing a wallet sized card for breath alcohol estimation. \\
\hline $\begin{array}{l}\text { Polymer Nanocomposite } \\
\text { Superconductors for Navy Applications }\end{array}$ & $\begin{array}{l}\text { Developing superconducting composite wires for high power lines in } \\
\text { confined spaces. }\end{array}$ \\
\hline Bodywater IC & An integrated circuit for measuring body water content. \\
\hline Wireless Jamming and Anti-Jamming & $\begin{array}{l}\text { Designing a system to prevent wireless communications across a } \\
\text { broadband spectrum during emergency situations. }\end{array}$ \\
\hline Tetris Game on GPIO & $\begin{array}{l}\text { Tetris game programmed on the DE0 + GPIO boards using Quartus II } \\
\text { software }\end{array}$ \\
\hline $\begin{array}{l}\text { Better Navigation: An App for Blind and } \\
\text { Visually Impaired }\end{array}$ & $\begin{array}{l}\text { Developing an app called Better Navigation, to be implemented in } \\
\text { Google Maps for the visually impaired. }\end{array}$ \\
\hline SAE Baja Vehicle DAQ & To create an on-board data acquisition system for the SAE Baja car. \\
\hline 3D Virtual Reality for Surgery & $\begin{array}{l}\text { Developing human cadaver in Unity with Steam VR prefabs for } \\
\text { surgery practice for trainee doctors }\end{array}$ \\
\hline WiFi Solar Power Monitor & Device to keep track of the solar power generated and consumed. \\
\hline Design, Build, \& Fly & $\begin{array}{l}\text { Design, manufacture, and successfully fly a remote-controlled aircraft } \\
\text { in the annual AIAA DBF competition }\end{array}$ \\
\hline Virtual Reality Hip Removal & VR reality of the hip replacement surgery procedure \\
\hline Formula Electric & Design, build test and drive a battery powered vehicle \\
\hline $\begin{array}{l}\text { Piezoelectric Roadside Energy } \\
\text { Harvesting }\end{array}$ & $\begin{array}{l}\text { Developing a laboratory setup in which piezoelectric harvesting units } \\
\text { would harvest and store energy from road vibrations. }\end{array}$ \\
\hline Digital Design: "Simon Says" & Creating "Simon Says" game using digital design process. \\
\hline Augmented Reality for Navy & $\begin{array}{l}\text { Creating an Augmented Reality application using the Unity 3D game } \\
\text { engine to train users in maintenance and repair tasks. }\end{array}$ \\
\hline Bioinspired Mechanical Small Robot & To design a small spider robot inspired by nature. \\
\hline Solar Tracking System & $\begin{array}{l}\text { Design a Solar tracker which would adjust the altitude and azimuth of } \\
\text { a solar cell panel normal to the external light source. }\end{array}$ \\
\hline
\end{tabular}

The objective of this work was to study the success or shortcomings of a course intervention motivated towards understanding the entrepreneurial mindset in students. The second objective was to develop an assessment criteria to measure the success of this effort by developing a grading rubric. Since the students were at their liberty to discuss any project of their choice, this led to a really very broad scope of studies submitted. This effort however provided the students 
with an opportunity to think along the 3 C's of entrepreneurial mindset. The projects were graded on a scale of 5 with 3 being satisfactory performance. Some of the projects have been summarized in the Table 1 along with their short descriptions.

\section{Assessment Method}

This class project was introduced to gauge the students' understanding of the $3 \mathrm{C}$ 's of the entrepreneurial mindset. Based on how well they could describe the technological as well as the business aspect of each of the 3C's the reports were graded. A rubric was developed as shown in Table 2 below

Table 2. Grading Rubrics

\begin{tabular}{|c|c|c|c|}
\hline 3C's & Excellent (5) & Adequate(3) & Not Adequate(1) \\
\hline CURIOSITY & $\begin{array}{l}\text { The report exemplifies curiosity } \\
\text { in that it poses impactful } \\
\text { questions that are relevant to the } \\
\text { activity, explains clearly and } \\
\text { succinctly what was learned, and } \\
\text { if applicable, raises relevant } \\
\text { questions for future work }\end{array}$ & $\begin{array}{l}\text { The report poses some } \\
\text { relevant questions and } \\
\text { contains some discussion of } \\
\text { what was learned, but some } \\
\text { opportunities or areas for } \\
\text { inquiry are overlooked or } \\
\text { glossed over }\end{array}$ & $\begin{array}{l}\text { The report contains no } \\
\text { real questions, and/or } \\
\text { gives a fatally flawed } \\
\text { analysis of what was } \\
\text { learned }\end{array}$ \\
\hline CONNECTIONS & $\begin{array}{l}\text { The report identifies all relevant } \\
\text { engineering principles and } \\
\text { provides a clear, accurate and } \\
\text { thorough explanation of how } \\
\text { they relate to and inform the } \\
\text { activity or project }\end{array}$ & $\begin{array}{l}\text { The report provides a } \\
\text { moderately useful overview } \\
\text { of engineering principles. } \\
\text { The discussion overlooks or } \\
\text { glosses over some relevant } \\
\text { principles and/or could be } \\
\text { clearer. }\end{array}$ & $\begin{array}{l}\text { The discussion of } \\
\text { relevant engineering } \\
\text { principles has } \\
\text { fundamental flaws- e.g., } \\
\text { it is incomprehensible } \\
\text { or contains significant } \\
\text { errors. }\end{array}$ \\
\hline $\begin{array}{l}\text { CREATING } \\
\text { VALUE }\end{array}$ & $\begin{array}{l}\text { The report identifies all relevant } \\
\text { forms of "value" (e.g., economic, } \\
\text { environmental, societal) and } \\
\text { provides a clear, accurate and } \\
\text { thorough analysis of how the } \\
\text { activity or project related to the } \\
\text { goal of creating value }\end{array}$ & $\begin{array}{l}\text { The report identifies and } \\
\text { discusses at least one } \\
\text { relevant form of "value". } \\
\text { The discussion could be } \\
\text { more in-depth and/or } \\
\text { clearer, but the points made } \\
\text { are valid }\end{array}$ & $\begin{array}{l}\text { There is no real } \\
\text { discussion of creating } \\
\text { value, or the discussion } \\
\text { has fundamental flaws. }\end{array}$ \\
\hline
\end{tabular}

The reports were graded and the results analyzed. The grading was done on a 5 point scale

Engineering Curiosity (5 points)

Business Curiosity ( 5 points)

Engineering Connections (5 points)

Business Connections (5 points)

Engineering Value Creation (5 points)

Business Value Creation (5 points)

The total score on the project was 30 points. The students being in their junior level were expected to be familiar with report writing and technical writing. 
We would like to give some examples from the student reports on how they described the work in their projects along the lines of 3C's. For the sake of brevity we will only list 4 projects.

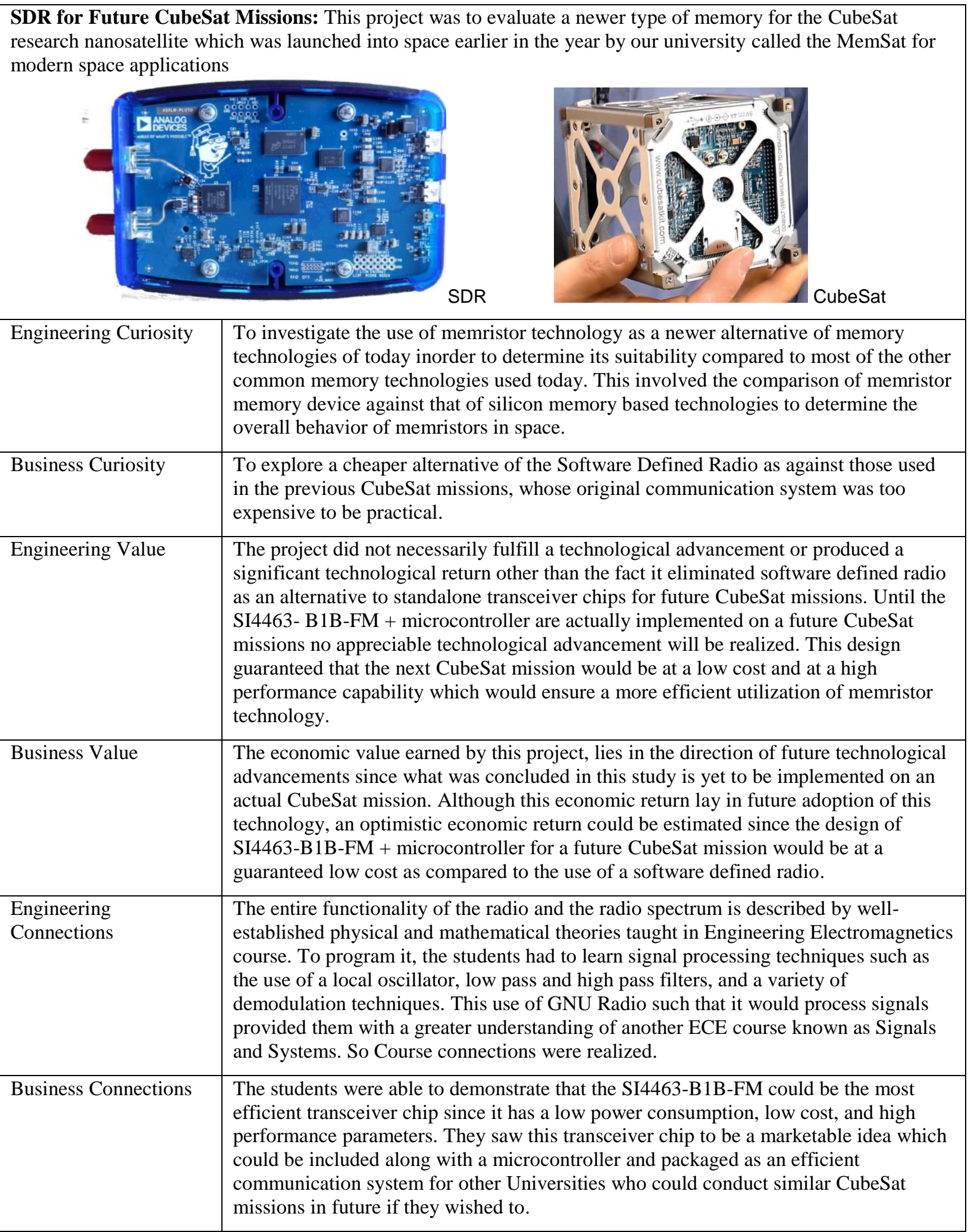




\begin{tabular}{|c|c|}
\hline $\begin{array}{l}\text { Accumulator Design } \\
\text { accumulator was expec } \\
\text { power the Formula Ele } \\
\text { research and providing }\end{array}$ & $\begin{array}{l}\text { Formula SAE: The accumulator consists of } 768 \text { Samsung } 18650 \text { battery cells. The } \\
\text { to reach a max voltage of } 403.2 \mathrm{~V} \text { with a capacity of } 16.0 \mathrm{Ah} \text {. The accumulator would } \\
\text { Vehicle which would compete in the competition. Project was about conducting } \\
\text { re documentation on the capabilities of battery technology in vehicles. }\end{array}$ \\
\hline & Formula Electric Vehicle \\
\hline Engineering Curiosity & $\begin{array}{l}\text { To investigate the capabilities of battery technology for powering Formula SAE } \\
\text { vehicles. By creating a unique battery pack the team would provide valuable } \\
\text { information on battery pack measurements, number of batteries and their configuration } \\
\text { in the vehicle power unit. The design results would be compared to the simulation } \\
\text { software results for validation. Would it be feasible to read the voltage, current, and } \\
\text { temperature of each accumulator segment continuously through charging and } \\
\text { discharging cycles using sensors connected to the accumulator? Could a higher C rate } \\
\text { (how quickly the batteries charge and discharge) be achieved? }\end{array}$ \\
\hline Business Curiosity & $\begin{array}{l}\text { One of the categories that the Formula Electric race car would be graded is on the } \\
\text { price of production. The students needed to figure out how to design a product } \\
\text { comparable to those available in the market for a much lower price. By using the } \\
\text { costing Template feature in Solidworks, would it be possible to produce modules for a } \\
\text { fraction of the price of their commercially available counterparts. Would these } \\
\text { modules save the team a lot of money }\end{array}$ \\
\hline Engineering Value & $\begin{array}{l}\text { By designing a fully electric race car that could reach extreme speeds like } 90 \mathrm{mph} \text { and } \\
\text { also go from 0-30mph in around } 3 \text { seconds, this project would demonstrate that } \\
\text { batteries are more than capable of just powering vehicles for normal driving } \\
\text { conditions. They can be used for race competitions too. It would provide a base model } \\
\text { for future design teams to work on for design improvement thus limiting the } \\
\text { environmental damage done by the gas powered vehicles. }\end{array}$ \\
\hline Business Value & $\begin{array}{l}\text { The Formula electric vehicle would provide exposure to our University on the global } \\
\text { scene. By competing successfully in the Formula SAE competition, this work would } \\
\text { provide many opportunities for partnerships and sponsorships for similar projects in } \\
\text { the University. While the university may benefit monetarily from this in the form of } \\
\text { technology commercialization, it will also benefit from an increase in prospective } \\
\text { student recruitment. The diversity and knowledge at the university is invaluable. }\end{array}$ \\
\hline $\begin{array}{l}\text { Engineering } \\
\text { Connections }\end{array}$ & $\begin{array}{l}\text { While designing the accumulator, the team found themselves referring to course } \\
\text { material from classes such as Principles of Electrical Circuit Analysis, and Electronics. } \\
\text { Figuring out how many batteries were needed and the necessary circuitry required } \\
\text { many calculations. These calculations included equations for values such as power, } \\
\text { kilowatt hours, voltage, and current. They were able to make related course } \\
\text { connections and became familiar with these equations in PECA. }\end{array}$ \\
\hline Business Connections & $\begin{array}{l}\text { The estimated final cost of the formula electric vehicle was } \$ 50,000 \text {. To acquire } \\
\text { funding for this project many professional relationships were made. The IEEE and } \\
\text { SAE technical societies agreed to provide } \$ 30,000 \text {. Stanley Black and Decker also } \\
\text { agreed to provide them with batteries for free. The students were offered help from the } \\
\text { professional staff of these companies in the form of any technical advice or experience } \\
\text { they may need in the area of battery usage. }\end{array}$ \\
\hline
\end{tabular}




\begin{tabular}{|c|c|}
\hline $\begin{array}{l}\text { Solar Tracking Syst } \\
\text { microcontroller to co } \\
\text { position of an externa } \\
\text { cell surface at a } 90^{\circ} \text { a } \\
\text { project consisted of d }\end{array}$ & $\begin{array}{l}\text { The solar tracker is a system that utilizes the versatility of an MSP430 series } \\
\text { servo motors that adjust the altitude and azimuth of a single solar cell according to the } \\
\text { t source. Since the solar cells absorb most of the light photons when they penetrate the } \\
\text { it is important to maintain this configuration to increase total power output. The } \\
\text { ing a prototype of the tracker and adjustor system. }\end{array}$ \\
\hline Isometric V & Side view - Rotor Assembly \\
\hline Engineering Curiosity & $\begin{array}{l}\text { To study about the single axis and dual axis trackers, their design and operation and } \\
\text { the various considerations such as installation size, local weather, degree of latitude } \\
\text { and electrical requirements that need to be accounted for. To anticipate the future } \\
\text { developmental trends in the tracker technology. }\end{array}$ \\
\hline Business Curiosity & $\begin{array}{l}\text { To look into what commercial factors led to the development of solar trackers, the } \\
\text { initial investment versus their long term returns. To understand the model of Time of } \\
\text { Use (TOU) rate plans for solar power by the utility companies. }\end{array}$ \\
\hline Engineering Value & $\begin{array}{l}\text { By investing technologies like a microcontroller, a few sensors, and } 2 \text { low-power } \\
\text { motors the outcome was a system that increases efficiency by achieving max power } \\
\text { output for a longer duration. The team learned that this same concept of using an error } \\
\text { of a subsystem to control and optimize the entire system can be used in other } \\
\text { applications such as high-efficiency HVAC systems. They understood the contribution } \\
\text { of low power systems in aiding high power systems for efficiency maximization. }\end{array}$ \\
\hline Business Value & $\begin{array}{l}\text { By adding a solar tracker to a solar panel an increase in the efficiency of the solar } \\
\text { panel is realized which is the simplest and most cost-effective method to increase } \\
\text { energy yield and thus is profitable to the solar panel industry. The economic value } \\
\text { invested would be the cost of the motor and the cost of the energy used by the motor. } \\
\text { The value gained would be the increase in efficiency from solar tracking. }\end{array}$ \\
\hline $\begin{array}{l}\text { Engineering } \\
\text { Connections }\end{array}$ & $\begin{array}{l}\text { The team could relate to their freshman year project where they worked on studying } \\
\text { various types of net-zero energy homes and their impact. These homes achieve net- } \\
\text { zero utility energy consumption by starting with a well-built home and combining that } \\
\text { with an on-site renewable energy source, usually solar. To design the system, } \\
\text { knowledge, and skills from other courses like Embedded Systems and Electronics } \\
\text { were found useful for the system control implementation of this project. Connections } \\
\text { with professors and teaching assistants helped the team to understand the theory } \\
\text { behind processor interfacing, which was used heavily in this project. }\end{array}$ \\
\hline Business Connections & $\begin{array}{l}\text { Due to the local nature of this small project, everything was completed in-house and } \\
\text { no significant business connection was made. However the prototyping maker space } \\
\text { which is a part of the College of Business was used, so some connections were made } \\
\text { there. }\end{array}$ \\
\hline
\end{tabular}




\begin{tabular}{|c|c|}
\hline \multicolumn{2}{|c|}{$\begin{array}{l}\text { AIAA Design, Build, and Fly: Students from various discipline collaborating to design, manufacture, and } \\
\text { successfully fly a remote-controlled aircraft in the annual AIAA DBF competition. The aircraft must satisfy } \\
\text { several criteria while still being able to complete the three flight missions and one ground mission during the } \\
\text { competition. The aim was to construct a multi-purpose aircraft within the size requirements that could perform } \\
\text { multiple carrier operations. }\end{array}$} \\
\hline \multicolumn{2}{|r|}{ Preliminary design } \\
\hline Engineering Curiosity & $\begin{array}{l}\text { To learn about different aspects of designing and building of a remotely - controlled } \\
\text { aircraft. To simulate interest in the aerospace engineering discipline, by creating } \\
\text { opportunity for early exposure to real world aircraft design principles, improvements } \\
\text { in fuel efficiency, aircraft performance, production costs, and safer transportation } \\
\text { option which would ultimately lead to increased recruitment and success in the field. } \\
\text { How to use the engineering software 'Solidworks' for CAD modeling of the aircraft, } \\
\text { 'Cura' for 3D printing components, and 'Laser Works' for laser cutting structural } \\
\text { components. }\end{array}$ \\
\hline Business Curiosity & $\begin{array}{l}\text { To learn about different ways aircraft manufacturers increase their business profits by } \\
\text { lowering production costs and minimizing losses, improving design concepts for better } \\
\text { fuel efficiency, reducing transportation costs by increase of space for packages and } \\
\text { passengers. }\end{array}$ \\
\hline Engineering Value & $\begin{array}{l}\text { The technological developments made during this project could contribute to the } \\
\text { improvement of aircraft design concepts for similar competitions. }\end{array}$ \\
\hline Business Value & $\begin{array}{l}\text { The economic value invested and earned by the project is unknown. If this project was } \\
\text { commercialized then it would have a value similar to other remote controlled airplane } \\
\text { toys in the market, which range from as cheap as } \$ 20 \text { to a few hundred dollars. }\end{array}$ \\
\hline $\begin{array}{l}\text { Engineering } \\
\text { Connections }\end{array}$ & $\begin{array}{l}\text { Connections were made between the knowledge acquired in other courses and the } \\
\text { ideas applied to this project, such as Introduction to Embedded Systems, Principles of } \\
\text { Mechanical Engineering for ECE Majors. Knowledge on Embedded Systems helped in } \\
\text { coding the different channels, buttons, and switches to their respective controls of the } \\
\text { aircraft while knowledge in Mechanical Engineering helped with propulsion of the } \\
\text { aircraft such as calculating the power requirement for a given weight of the aircraft as } \\
\text { well as knowing how gears, pulleys, hinges, servos, supports, and gravity played a role } \\
\text { in effective aircraft performance. }\end{array}$ \\
\hline Business Connections & $\begin{array}{l}\text { Professional connections were established with fellow mechanical engineering } \\
\text { students while working with them. Also connection between the DBF project and its } \\
\text { commercial marketability was thought of. The project budget covered by the } \\
\text { university was } \$ 1000 \text { while the total budget was } \$ 2129 \text {. Therefore, the team had to } \\
\text { make fundraising connections inorder to raise the remaining } \$ 1129 \text {. }\end{array}$ \\
\hline
\end{tabular}




\section{Results and Discussion}

There were a total of 43 project reports. The team sizes ranged from single member teams to four membered teams. The lowest score was 10 while the highest score was 30 . The mean score was 21. Based on the scores in each sections of the report it was observed that the students scored relatively well on the Curiosity aspect of the project, but fell short when discussing the Value creation part of the project. Figure 2 shows a pi-chart of the percentage of the total score on each section of the report, Curiosity, Connections, and Creating value as a whole. The score on the Curiosity being the highest, shows that the students understood and described the curiosity factor well. This could be a result of the environment that the subjects (students) were in. In academic research the curiosity takes a preference and is the driving force for institutional research. Curiosity here was considered to be the desire to find out if a particular technology works, or does it work better that its competitors, or simply the desire to do something new and see if it works. Similarly in an industrial setting creating value would probably take a preference.

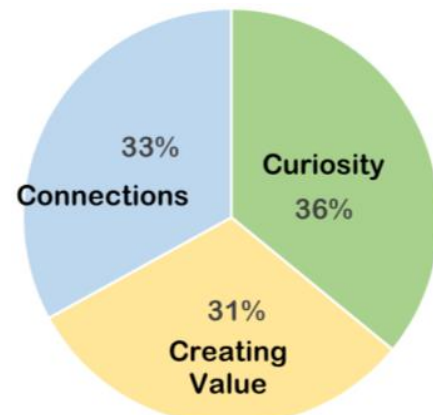

Figure 2. Percentage score for each of the $3 \mathrm{C}$ 's based on the student reports.

Since the number of projects were $\mathrm{N}=43$, the maximum score possible in any category was $5 * 43=215$. In Figure 3 the mean score is presented along with the standard errors. The mean scores on the Engineering Curiosity and the Engineering connections sections was far better than the rest of the sections.

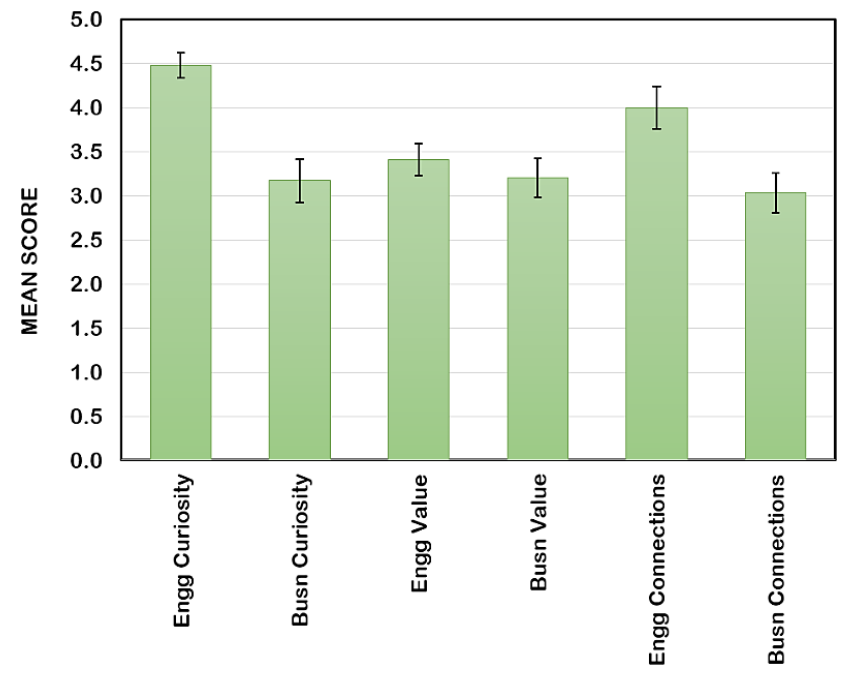

Figure 3. The mean score obtained in each component of the 3C's 
The mean scores and the standard errors are given below in Table 3. We can see that the scatter was significantly less for Engineering factors section as compared to the Business factors. Engineering Curiosity had the least standard error among the engineering factors. Within the Business factors of the project the standard error in score was least for Business Value. Both the highest mean and the smallest standard error tell us that these are the factors the students are best at. The displayed a strong engineering curiosity towards their projects and understood the business or commercial worth of their project very well. This conclusion is supported by the observation that the reports were well written under these two sections in comparison to the rest.

Table 3. Mean scores and the standard errors

\begin{tabular}{|l|c|l|l|l|c|c|}
\hline & $\begin{array}{l}\text { Engineering } \\
\text { Curiosity }\end{array}$ & $\begin{array}{l}\text { Business } \\
\text { Curiosity }\end{array}$ & $\begin{array}{l}\text { Engineering } \\
\text { Value }\end{array}$ & $\begin{array}{l}\text { Business } \\
\text { Value }\end{array}$ & $\begin{array}{l}\text { Engineering } \\
\text { Connections }\end{array}$ & $\begin{array}{l}\text { Business } \\
\text { Connections }\end{array}$ \\
\hline Mean & 4.48 & 3.17 & 3.41 & 3.21 & 4.00 & 3.03 \\
\hline $\begin{array}{l}\text { Standard } \\
\text { Error }\end{array}$ & 0.145 & 0.248 & 0.182 & 0.218 & 0.238 & 0.230 \\
\hline
\end{tabular}

A student's t-test was also carried out on the project scores. The p-values and t-values are presented in Table 4. Since the t-values are higher than the probability values the data is statistically significant. The extremely low p-value for curiosity shows that the students had a much better understanding, and hence a consistently higher score on that element of entrepreneurial mindset. The second lowest $\mathrm{p}$-value is for connections and is in part due to the students' ability to make connections between their project and the various classroom courses taught or internship experience acquired or technical conferences attended and hence obtain consistently high scores on Engineering Connections. The 'null hypothesis' here is that there is no relationship between the measured parameters and the student's performance.

Table 4. The t-values and p-values for $3 \mathrm{Cs}$

\begin{tabular}{|c|c|c|c|}
\hline & Curiosity & $\begin{array}{c}\text { Creating } \\
\text { Value }\end{array}$ & Connections \\
\hline t-value & 4.5488 & 0.7268 & 2.9169 \\
\hline p-value & $2.93 \mathrm{E}-05$ & 0.4703 & 0.0051 \\
\hline
\end{tabular}

Overall the reports were well written for the Engineering factors than for the Business factors as is noticeable from the scores too. This may suggest that encouraging the engineering students to relate to the economic curiosity, value and connections is required and needs to be emphasized in entrepreneurial education.

Table 5. The Engineering and Business Values described in the reports were mostly

\begin{tabular}{|l|l|}
\hline Engineering Value & $\begin{array}{l}\text { 1. } \\
\text { 2. }\end{array}$ \\
$\begin{array}{l}\text { 3. } \\
\text { To advance the state of the art } \\
\text { Even if the work was not contributing to any sort of technological advancement, } \\
\text { the project was novel in concept and implementation }\end{array}$ \\
\hline Business Value & $\begin{array}{l}\text { 1. Work leading to commercialization of the product. } \\
\text { 2. Work leading to cost factor reduction }\end{array}$ \\
\hline
\end{tabular}




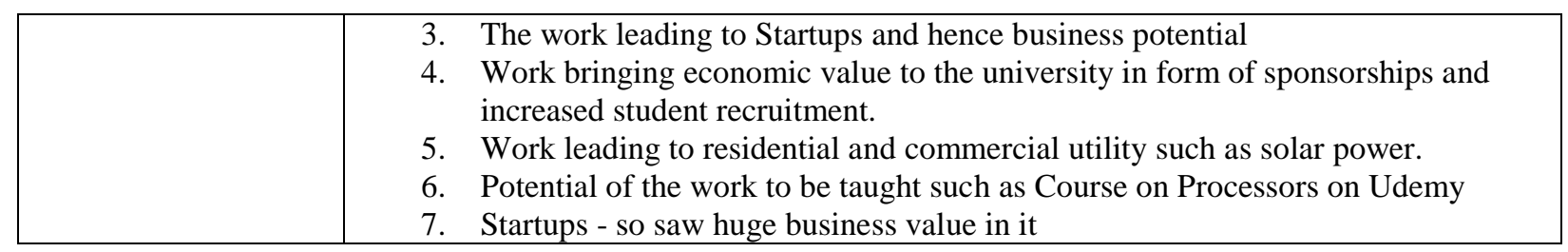

Table 6. The common connections that were described in the reports was

\begin{tabular}{|c|c|}
\hline $\begin{array}{l}\text { Engineering } \\
\text { Connections }\end{array}$ & $\begin{array}{l}\text { 1. Made connections within College with technicians, friends, professors, grad } \\
\text { students. } \\
\text { 2. Connections to engineering community on online forums too. } \\
\text { 3. Interdepartmental Connections like ECE students worked on MechE shop } \\
\text { facilities } \\
\text { 4. Connections to engineering courses, past projects, certain technologies (net } \\
\text { zero home technology) } \\
\text { 5. Connections to professional societies and conferences like IEEE Sensor } \\
\text { Application Symposium } \\
\text { 6. Connections with local engineering companies, within interning company } \\
\text { 7. Connection made with Alumni } \\
\text { 8. Connections made with certain protocols and practices such as Inter- } \\
\text { Integrated Circuit (I2C) and the Serial Peripheral Interface (SPI) protocols. }\end{array}$ \\
\hline Business Connections & $\begin{array}{l}\text { 1. Connection made with the idea of business prospects e.g., industrial } \\
\text { automation, manufacturing, biomedical systems, and consumer electronics } \\
\text { 2. Connections made with companies and sponsors, } \\
\text { 3. Connections made to companies in the University Innovation Park, Maker } \\
\text { Spaces or the Additive Manufacturing units of University. } \\
\text { 4. Connections made in Entrepreneurship Competitions and with other } \\
\text { entrepreneurs. } \\
\text { 5. Connections made at Trade shows, } \\
\text { 6. Connections made with certain professional skills like learning project } \\
\text { management skills }\end{array}$ \\
\hline
\end{tabular}

On the Creating Value component the student responses were mostly alike. For them creating Engineering or Business value meant making a similar product but on a lower cost price basis, developing a technology to cut down on costs, or simply the total economic value of executing their project. The students were unable to take a distant perspective of the economical or technological contribution that their work could make, or how their work could fit into related technological or commercial developments of the present times.

In a further continuation of this study it is suggested that pre- and post- assessment of the student projects be done along with certain additional data collection such as group interviews. This will help us to narrow down on the factors that challenge the $3 \mathrm{C}$ model of entrepreneurial mindset in students. It is also recommended that an in-depth study be carried out focusing on any of the C's one at a time. Additionally the method of data collection could be done on the academic year basis in an effort to identify evolution of student response with their time in program. The mindset of the senior level students might be different from that of freshmen level students due to college experiences. 
The class was over all well-liked by the students. Some feedback comments from the students were

"The class was pretty relevant in some aspects of your major. It is important to understand this subject because interdisciplinary work is very common plus a lot interesting"

"The course provided a helpful and unique educational perspective to Mechanical Engineering"

"This course helps ECE majors understand some topics outside of their focus. This is a good course to help broaden your options.."

\section{Conclusions}

A study was carried out to gauge the students' understanding of the 3C's of the entrepreneurial mindset. Based on how well they could describe the technological as well as the business aspect of each of the 3C's the reports were graded. Each group had to choose an interesting project that they had been a part of and discuss it along the lines of Engineering Curiosity and Business Curiosity behind the project, Engineering Connections and Business Connections made, Engineering Value and Business Value created. It was observed that the students scored relatively well on the Curiosity aspect of the project, but fell short when discussing the Value creation part of the project. The mean scores on the Engineering Curiosity and the Engineering connections sections was far better than the rest of the sections. In a further continuation of this study it is suggested that pre- and post- assessment of the student projects be done along with certain additional data collection such as group interviews. This will help us to narrow down on the factors that challenge the $3 \mathrm{C}$ model of entrepreneurial mindset in students.

This work was supported by a Curriculum Innovation Grant provided by funding received from the Kern Family Foundation through the KEEN network. 


\section{References}

[1] M. Al-Atabi, D. Kum Tien, "A Blueprint for implementing Grand Challenge Scholars' Programme: A Case Study of Taylor's University," Journal of Engineering Science and Technology, Special Issue April 2003, pp. 80-86.

[2] T. Byers, T. Seelig, S. Sheppard, P. Weilerstein, "Entrepreneurship: It's Role in Engineering Education," The Bridge, p. 35, Summer 2013.

[3] A. Richert-Kaźmierska, E. Lechman, Chapt 1, 2. Creating Entrepreneurial Mindset, University College Denmark, 2014.

[4] L. Bosman, B. Mayer, P. McNamara, "Promoting Entrepreneurially Minded Learning through Online Discussions," presented at 124th ASEE Annual Conference \& Exposition, June 25-28, Columbus, OH, 2017.

[5] M. Taks, P. Tynjala, M. Toding, "Engineering Students' Experiences in Studying Entrepreneurship," Journal of Engineering Education, Vol. 103, No. 4, pp. 573-598, 2014.

[6] D. Pistrui, J. Blessing, K. Mekemson, "Building an Entrepreneurial Engineering Ecosystem for Future Generations: The Kern Entrepreneurship Education Network," presented at 115th ASEE Annual Conference \& Exposition, June 22-25, Pittsburgh, PA, 2008.

[7] D. Rae, and D. Melton, "Developing an Entrepreneurial Mindset in US Engineering Education: An International View of the KEEN Project," The Journal of Engineering Entrepreneurship, vol. 7, no. 3, 2017.

[8] L. Liu, J. Mynderse, A. Gerhart, S. Arslan, "Fostering the Entrepreneurial Mindset in the Junior and Senior Mechanical Engineering Curriculum with a Multi-Course Problem-Based Learning Experience", presented at IEEE Frontiers in Education Conference (FIE), October 21 24, 2015, Washington, DC.

[9] S. Zappe, J. Yoder, J. Hylton, "Assessing Curiosity in the Engineering Entrepreneurship context: Challenges and Future Research areas," Advances in Engineering Education, pp. 1-10, Nov 2018. 